\title{
Stem cell hearing stirs bioethics debate
}

A flurry of activity involving research on human embryonic stem cells has stirred interests among high officials in the federal government, including US President Bill Clinton, as well as ranking Republicans and Democrats from the US Senate Appropriations Committee Subcommittee on Labor, Health and Human Services, Education and Related Agencies (LHHSERA). During a subcommittee hearing last December, some members of Congress indicated they might ease the current ban on federal funding for virtually all research involving human embryos. As well as enabling many more investigators to apply human embryonic stem cell research to more disease areas, some bioethicists think the change would allow a broader oversight of the field.

Two biotechnology companies, Geron (Menlo Park, CA) and Advanced Cell Technology (ACT; Worcester, MA), recently released reports of human embryonic stem cell achievements. Although they were both criticized for undermining the credibility of the biotechnology industry (Nat. Biotechnol. $16: 1291,1998)$, the announcements contributed to the renewed public debate.

Researchers at academic institutions who are collaborating with investigators at Geron reported last November two somewhat different methods for recovering cells from human embryos, culturing some of the pluripotent stem cells in vitro, and potentially inducing such cells to differentiate into specific cell types. In one case, John Gearhart at Johns Hopkins University School of Medicine (Baltimore, MD) and his collaborators extracted cells from the gonadal region of human embryos from terminated pregnancies. In the other case, James Thomson of the Wisconsin Primate Research Center at the University of Wisconsin (Madison, WI) and his colleagues obtained cells from the inner cell mass of human embryos that had been produced and stored, but were to be discarded, at in vitro fertilization clinics. Although the cultured stem cells derive from human embryos, "they are unable to form embryos or develop into humans," says Gearhart, countering criticism regarding the ethics of using cells derived from embryos.

Meanwhile, researchers at ACT say they have developed a procedure for introducing nuclei from differentiated human cells into enucleated cow embryo cells, thereby producing human-like stem cells that also can be cultured stably in vitro. "We recently announced our preliminary results to stimulate debate and elicit guidelines for this research to go forward," says Michael West, ACT's president and CEO. "The recombinant DNA debate was also about mixing across species, but this is a more profound debate today because it can involve mixing whole chromosomes."

When Clinton learned of the ACT experiments in mid-November, he immediately asked members of the National Bioethics Advisory Commission (NBAC; Washington, DC) to review this and related research undertakings involving human stem cells. NBAC Executive Director Eric Meslin says that the commission plans to deliver a comprehensive review of the bioethical and legal implications of such research to the president by early spring.

Before NBAC members conduct their review, Senator Arlen Specter (R-PA), who chairs the LHHSERA subcommittee, and Senator Tom Harkin (D-IA), the top Democrat on the subcommittee, launched their own inquiry into the legal, ethical, and biomedical implications of this research. Although stem cells have the "potential for treating a wide variety of serious illnesses," says Specter, "this subject is highly charged."

"The scientific potential is awe-inspiring, and my hope is that this research will be allowed to go forward," says Harkin. "Maybe what we're looking for is for the ban to be lifted and replaced with strong guidelines." He also says that potential medical benefits that may be realized from such research will depend, in part, on the development of "healthy partnerships between the federal and private sectors."

The development of such partnerships is severely restricted now because Congress currently prohibits the US National Institutes of
Health (NIH; Bethesda, MD) from spending federal money on virtually all research involving human embryos. Whether that ban extends to stem cells derived from human embryos is not clear, according to NIH Director Harold Varmus. Such stem cells "can't give rise to a human being and cannot be considered embryos," he says. "However, the use of cells... obtained from early human embryos raised concerns, and these views must be taken into consideration. We see enormous promise in such research, but also respect existing laws and. . .need to be sure any actions we take are in compliance with the law."

Easing of the federal ban would have both scientific and ethical effects. "The number of diseases that could be targeted would expand exponentially if the federal ban on research were not in place," says Thomson of the University of Wisconsin. It would also greatly expand the scope of basic research efforts that investigators in both the private and public sector say will be needed to help in reaping practical benefits from stem cell research. "NIH should participate because the industry will explore only that path that leads to products," says Thomas Okarma, Geron's vice-president for R\&D.

Public funding for such research will also help to assure there is broad oversight of developments in this field, according to Arthur Caplan, who directs the Center for Bioethics for the University of Pennsylvania Health System (Philadelphia, PA). "If it is left to the private sector, the field will develop slowly and in secret," he says. "That is not a desirable outcome of public policy."

Jeffrey L. Fox

\section{Battle lines redrawn in BTWC debate}

In the ongoing debate over the terms of a new enforcement protocol for the Biological and Toxin Weapons Convention (BTWC), biotechnology trade groups have consistently opposed an inspection regime advocated by some weapons control experts. But now they are facing new opponents: defectors from within. Thomas Monath, vice-president for research at OraVax (Cambridge, MA), a biotechnology company that develops vac-

Alan Dove is a freelance writer working in New York. cines against biological weapons, and Lance Gordon, the company's CEO, have broken ranks with trade groups and support a robust BTWC enforcement regime, including clarification visits (Science 282:1423, 1998).

The BTWC calls for two types of inspections: challenge inspections and clarification visits. Challenge inspections are relatively uncontroversial and must be supported by convincing evidence of treaty violation. Clarification visits, on the other hand, are more routine inspections of declared biotechnology and pharmaceutical facilities, and require no evidence of biological weapons 